\title{
Leaf Colour Chart for Proficient Nitrogen Management in Transplanted Rice (Oryza sativa L.) in Eastern Uttar Pradesh, India
}

\author{
Sheikh Amir Ali ${ }^{1}$, S. Elamathi ${ }^{2}$, Suryendra Singh ${ }^{3 *}$, \\ Victor Debbarma ${ }^{1}$ and Gautam Ghosh ${ }^{1}$
}

${ }^{1}$ Department of Agronomy, Naini Agricultural Institute, Sam Higginbottom Universitry of

Agriculture, Technology and Sciences, Allahabad - 211007, U.P., India

${ }^{2}$ Tamil Nadu Agricultural University, Coimbatore - 641003, Tamil Nadu, India

${ }^{3}$ Guru Angad Dev Veterinary and Animal Sciences University,

Ludhiana - 141004, Punjab, India

*Corresponding author

\begin{tabular}{|c|c|}
\hline & $\mathbf{N}$ \\
\hline & \multirow{6}{*}{ 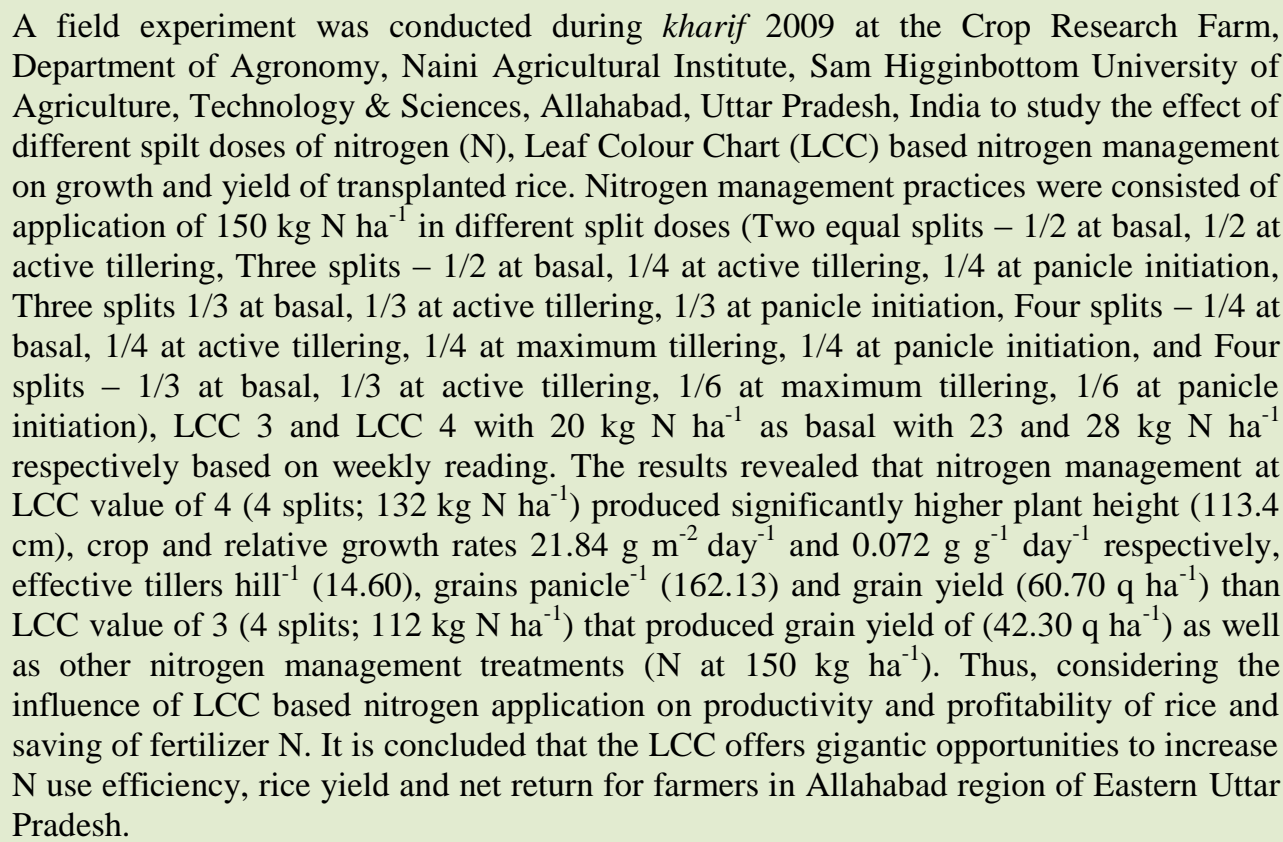 } \\
\hline Keywords & \\
\hline $\begin{array}{l}\text { Rice, Leaf Colour } \\
\text { Chart, Productivity, } \\
\text { Economics. }\end{array}$ & \\
\hline Article Info & \\
\hline $\begin{array}{l}\text { Accepted: } \\
30 \text { September } 2017 \\
\text { Available Online: } \\
10 \text { November } 2017\end{array}$ & \\
\hline & \\
\hline
\end{tabular}

\section{Introduction}

Nitrogen $(\mathrm{N})$ fertilizer is necessary input in most rice soils to accomplish high yield. Current fertilizer $\mathrm{N}$ recommendations in Allahabad region of Eastern Uttar Pradesh typically consist of fixed rate and timings for large rice growing tracts. These 'blanket' recommendations have served their purpose in producing good yields, but they are limited in their capacity to increase nutrient use efficiency. Many times, to ensure high yields, 
farmers apply fertilizer $\mathrm{N}$ rates even higher than the blanket recommendation. Over application of $\mathrm{N}$ in rice crop leads to further lowering of $\mathrm{N}$ fertilizer recovery efficiency. The blanket recommendations are also not responsive to temporal variations in crop $\mathrm{N}$ demand. Use of $\mathrm{N}$ in excess of crop requirement and inefficient splitting of $\mathrm{N}$ applications are the main reasons for low $\mathrm{N}$ use efficiency in rice. Since improving the synchrony between crop $\mathrm{N}$ demand and the $\mathrm{N}$ supply from soil and or the applied $\mathrm{N}$ fertilizer is likely to be the most promising strategy to increase $\mathrm{N}$ use efficiency, the split application of fertilizer $\mathrm{N}$ is going to remain an essential component of fertilizer $\mathrm{N}$ management strategies in rice [1]. Real-time corrective $\mathrm{N}$ management is based on periodic assessment of plant $\mathrm{N}$ status, and the application of fertilizer $\mathrm{N}$ is delayed until $\mathrm{N}$ deficiency symptoms start to appear. Thus, a key ingredient for real-time $\mathrm{N}$ management is a method of rapid assessment of leaf $\mathrm{N}$ content that is closely related to photosynthetic rate and biomass production and is a sensitive indicator of changes in crop $\mathrm{N}$ demand within the growing season. As rice leaf colour is a good indicator of leaf $\mathrm{N}$ content, the LCC, developed through collaboration of the International Rice Research Institute [2] with agricultural research systems of several countries in Asia, serves as a visual and subjective indicator of plant $\mathrm{N}$ deficiency. Use of this approach in developing countries of Asia is very limited. LCC provide a simple, quick, and nondestructive method for estimating $\mathrm{N}$ of rice leaves. Very limited research work is available so far to establish LCC for rice in Eastern India, particularly in Uttar Pradesh. Therefore, the present investigation was conducted to evaluate real-time $\mathrm{N}$ fertilizer management with the LCC relative to the 'blanket' recommendations with the following objectives: (1) to save $\mathrm{N}$ without decreasing yield of rice, (2) to avoid expenditure on soil test for the recommendation of $\mathrm{N}$ fertilizers and (3) to find out the relative efficiency of LCC for the $\mathrm{N}$ economy as well as increasing yield.

\section{Materials and Methods}

The field experiment was conducted during rainy season (kharif) of 2009 in Randomized Block Design with three replications at Crop Research Farm, Department of Agronomy, Sam Higginbottom University of Agriculture, Technology \& Sciences, Allahabad, Uttar Pradesh, India. The field was sandy loam in texture, taxonomically known asoxisols and neutral in $\mathrm{pH} 7.1$ and the $\mathrm{EC}$ was $0.24 \mathrm{dSm}^{-1}$. The soil was low $\left(202 \mathrm{~kg} \mathrm{ha}^{-1}\right)$ in available $\mathrm{N}$, medium high $\left(32 \mathrm{~kg} \mathrm{ha}^{-1}\right)$ in available $\mathrm{P}$ and low $\left(93.5 \mathrm{~kg} \mathrm{ha}^{-1}\right)$ in available K. Treatments were consisted of application of $150 \mathrm{~kg} \mathrm{~N} \mathrm{ha}^{-1}$ in different split doses (Two equal splits $-1 / 2$ at basal, 1/2 at active tillering, Three splits $1 / 2$ at basal, $1 / 4$ at active tillering, $1 / 4$ at panicle initiation, Three splits $1 / 3$ at basal, $1 / 3$ at active tillering, $1 / 3$ at panicle initiation, Four splits $-1 / 4$ at basal, $1 / 4$ at active tillering, $1 / 4$ at maximum tillering, $1 / 4$ at panicle initiation, and Four splits $-1 / 3$ at basal, 1/3 at active tillering, 1/6 at maximum tillering, $1 / 6$ at panicle initiation), Leaf Colour Chart (LCC) based nitrogen application (LCC $3-20 \mathrm{~kg}$ basal $+23 \mathrm{~kg} \mathrm{~N}$ $\mathrm{ha}^{-1}$ based on weekly reading and LCC $4-20$ $\mathrm{kg}$ basal $+28 \mathrm{~kg} \mathrm{~N} \mathrm{ha}^{-1}$ based on weekly reading (Tables 1 and 2). A common fertilizer dose of 75: $60 \mathrm{~kg} \mathrm{P}$ and $\mathrm{K} \mathrm{ha}^{-1}$ was adopted. The entire dose of $\mathrm{P}$ and $\mathrm{K}$ with $25 \mathrm{~kg} \mathrm{ZnSO}_{4}$ $\mathrm{ha}^{-1}$ were applied basal to rice crop, and nitrogen as urea was applied as per the treatment schedule. Nitrogen management through LCC values of 3 and 4 in four splits were done with 112 and $132 \mathrm{~kg} \mathrm{~N} \mathrm{ha}{ }^{-1}$ respectively. 22 days old seedlings of rice 'Pro-Agro 6444' were transplanted at $20 \mathrm{~cm} \mathrm{x}$ $10 \mathrm{~cm}$ spacing on $1 \mathrm{July}, 2009$. All improved packages of practices were followed to raise 
the crop and the data were statistically analyzed using the $F$-test.

\section{Leaf colour chart (LCC)}

LCC developed by the Nitrogen Parameters, Chennai, India (Fig. 1) with six green shades ranging from yellowish green (which is number 1 on the chart) to dark green (which is number 6) was used in the trial. LCC readings were taken at 7 days interval starting from 14 days after transplanting (DAT) till 10\% flowering. 10 disease free hills were selected at random from the sampling area in each plot where plant distribution was uniform.

From each hill top most fully expanded leaf was selected and LCC readings were taken by placing the middle part of the leaf on top of LCC's colour strips and the leaf colour was observed by keeping the sun blocked by body as sun light affects leaf colour reading by same person. Whenever the green colour of 6 out of 10 leaves were observed below the critical value, nitrogen was applied as per the LCC value.

\section{Results and Discussion}

\section{Growth parameters}

Growth parameters like plant height, crop and relative growth rates (CGR and RGR)) and effective tillers of transplanted rice were positively influenced by different nitrogen management practices. Significantly higher plant height $(113.4 \mathrm{~cm})$, crop growth rate $\left(21.01 \mathrm{~g} \mathrm{~m}^{-2}\right.$ day $\left.^{-1}\right)$ and relative growth rate $\left(0.072 \mathrm{~g} \mathrm{~g} \mathrm{~g}^{-1}\right.$ day $\left.^{-1}\right)$ were obtained with nitrogen application based on LCC value of 4 (4 splits; $132 \mathrm{~kg} \mathrm{~N} \mathrm{ha}^{-1}$ ) as compared to LCC value 3 (4 splits; $112 \mathrm{~kg} \mathrm{~N} \mathrm{ha}^{-1}$ ), however, CGR was on par with four splits $-1 / 4$ at basal, 1/4 at active tillering, 1/4 at maximum tillering, $1 / 4$ at panicle initiation only at the same time as relative growth rate was at par with application of nitrogen in four splits $1 / 4$ at basal, 1/4 at active tillering, 1/4 at maximum tillering, $1 / 4$ at panicle initiation, four splits $-1 / 3$ at basal, $1 / 3$ at active tillering, $1 / 6$ at maximum tillering, $1 / 6$ at panicle initiation and LCC value 3 (4 splits; $112 \mathrm{~kg} \mathrm{~N} \mathrm{ha}^{-1}$ ) (Table 1). Among the split doses of nitrogen, application of $-1 / 4$ at basal, 1/4 at active tillering, 1/4 at maximum tillering, 1/4 at panicle initiation registered higher plant height, crop and relative growth rates (CGR and RGR) over two equal splits $1 / 2$ at basal, $1 / 2$ at active tillering, three splits $-1 / 2$ at basal, $1 / 4$ at active tillering, 1/4 at panicle initiation, three splits $1 / 3$ at basal, $1 / 3$ at active tillering, $1 / 3$ at panicle initiation, and four splits $-1 / 3$ at basal, $1 / 3$ at active tillering, 1/6 at maximum tillering, 1/6 at panicle initiation. Effective tillers hill $^{-1}$ (14.60) was significantly higher under LCC value 4 (4 splits; $132 \mathrm{~kg} \mathrm{~N} \mathrm{ha}^{-1}$ ) over LCC value 3 ( 4 splits; $112 \mathrm{~kg} \mathrm{~N} \mathrm{ha}^{-1}$ ) and it was at par with rest of the nitrogen management practices except application of nitrogen in three splits $-1 / 2$ at basal, $1 / 4$ at active tillering, $1 / 4$ at panicle initiation. Application of nitrogen in splits according to the crop requirements was the motive for better rice growth parameters. The usefulness of increased $\mathrm{N}$ application on tiller production was also observed by [3].

\section{Yield attributes}

Various nitrogen management practices showed significant difference on grains panicle $^{-1}$ of transplanted rice. However, they failed to exert any influence on length of panicle, $2^{\text {nd }}$ test weight. Among the nitrogen management practices, LCC value 4 (4 splits; $132 \mathrm{~kg} \mathrm{~N} \mathrm{ha}^{-1}$ ) produced higher number of grains panicle $^{-1}$ (162.13) and it was at par with nitrogen application in three splits $-1 / 3$ at basal, $1 / 3$ at active tillering, $1 / 3$ at panicle initiation. Nitrogen management at LCC value 3 (4 splits; $112 \mathrm{~kg} \mathrm{~N} \mathrm{ha}^{-1}$ ) registered 
significantly lower number of grains panicle ${ }^{-1}$ (140.66) over LCC 4 (4 splits; $132 \mathrm{~kg} \mathrm{~N} \mathrm{ha}^{-1}$ ) (Table 2). The $\mathrm{N}$ recovery efficiency of rice crop varies with crop stage. According to [4], the recovery efficiency of top-dressed urea during peak demand periods of rice, such as panicle initiation, was as high as $78 \%$. Matching N supplies with crop demand, therefore, increases its recovery efficiency by the crop. Fertiliser $\mathrm{N}$ applied when crop demand is low is subject to losses leading to low $\mathrm{N}$ use efficiency. That is why perhaps rice yield attributes and yield in the present study were higher with LCC value 4 than other treatments. This was in accordance with the findings of $[5,6]$

Fig.1 Leaf colour chart with six colour shades developed by nitrogen parameters

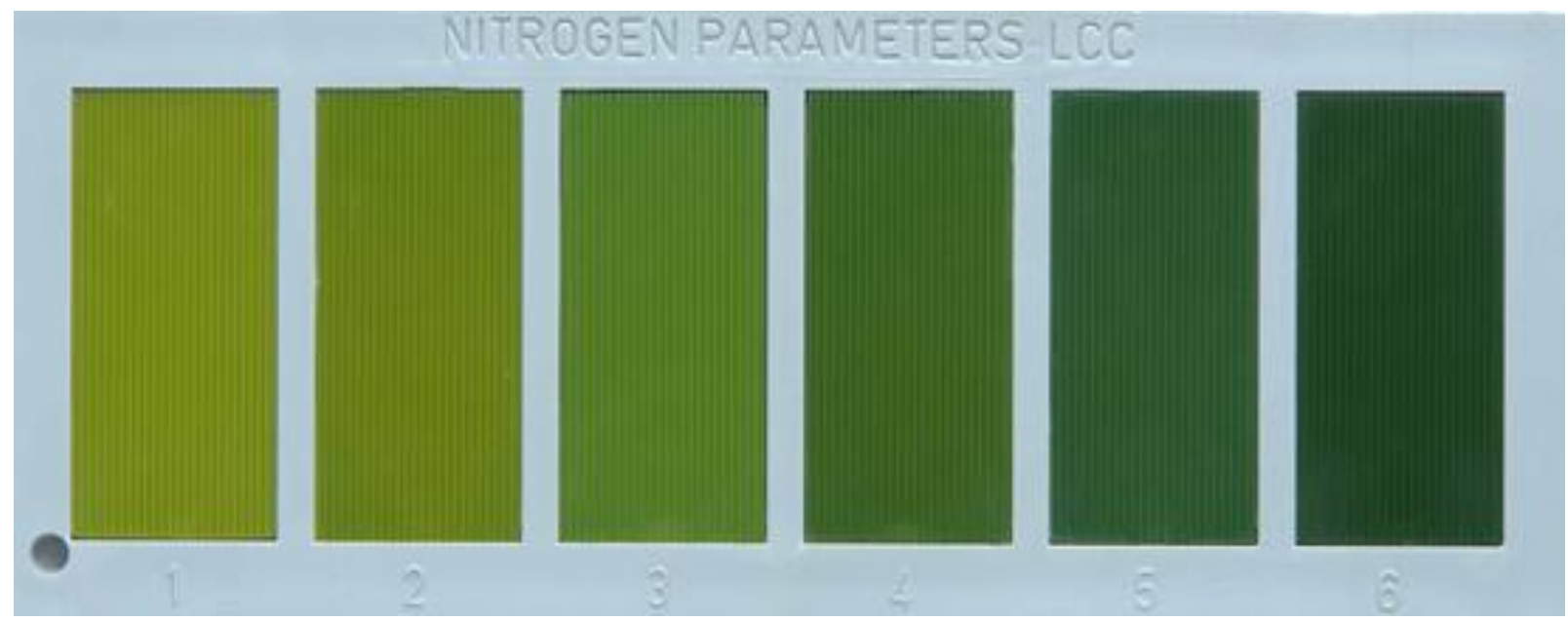

Fig.2 Yield response to fertilizer N

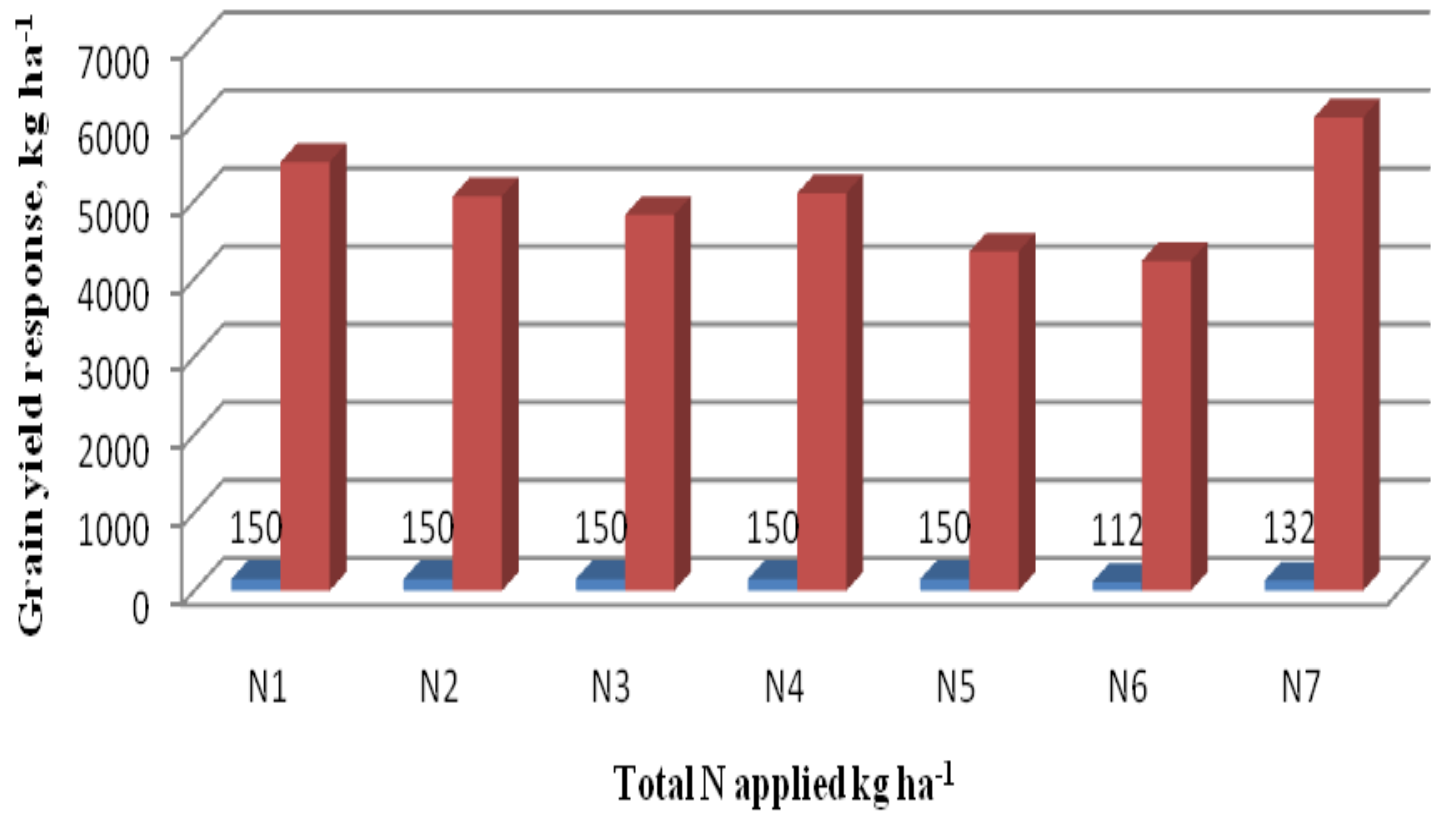


Table.1 Effect of nitrogen management on growth characters of transplanted rice

\begin{tabular}{|c|c|c|c|c|c|c|}
\hline Treatment & $\begin{array}{l}\text { Number } \\
\text { of splits }\end{array}$ & $\begin{array}{l}\text { Total N applied } \\
\left(\mathrm{kg} \mathrm{ha}^{-1}\right)\end{array}$ & $\begin{array}{c}\begin{array}{c}\text { Plant } \\
\text { height } \\
(\mathrm{cm})\end{array}\end{array}$ & $\begin{array}{l}\text { CGR } \\
\mathrm{g} \mathrm{m}^{-2} \\
\text { day }^{-1}\end{array}$ & $\begin{array}{l}\text { RGR } \\
g^{-1} g^{-1} \\
\text { day }^{-1}\end{array}$ & $\begin{array}{c}\text { Effective } \\
\text { tillers hill } \\
1\end{array}$ \\
\hline $\begin{array}{c}\mathrm{N} 1- \\
1 / 2+1 / 2\end{array}$ & 2 & $75+75=150$ & 104.80 & 19.15 & 0.052 & 14.53 \\
\hline $\begin{array}{c}\mathrm{N} 2- \\
1 / 2+1 / 4+1 / 4\end{array}$ & 3 & $75+37.5+37.5=150$ & 102.40 & 16.10 & 0.047 & 11.66 \\
\hline $\begin{array}{c}\mathrm{N} 3- \\
1 / 3+1 / 3+1 / 3\end{array}$ & 3 & $50+50+50=150$ & 105.13 & 18.60 & 0.056 & 13.26 \\
\hline $\begin{array}{l}\mathrm{N} 4- \\
1 / 4+1 / 4+1 / 4+1 / 4\end{array}$ & 4 & $\begin{array}{c}37.5+37.5+37.5+37.5 \\
=150\end{array}$ & 107.53 & 20.08 & 0.069 & 13.86 \\
\hline$\frac{\mathrm{N} 5-}{1 / 3+1 / 3+1 / 6+1 / 6}$ & 4 & $50+50+25+25=150$ & 105.66 & 19.70 & 0.067 & 13.86 \\
\hline $\begin{array}{c}\mathrm{N}_{6^{-}}-\mathrm{LCC} 3-20 \mathrm{~kg} \text { basal }+23 \mathrm{~kg} \mathrm{~N} \\
\text { ha }^{-1} \text { based on weekly reading }\end{array}$ & 4 & $23+23+23+23=112$ & 99.00 & 17.58 & 0.065 & 10.26 \\
\hline $\begin{array}{l}\text { N7- LCC4-20 kg basal + } 28 \mathrm{~kg} \mathrm{~N} \\
\mathrm{ha}^{-1} \text { haced on w/eeklv readino }\end{array}$ & 4 & $28+28+28+28=132$ & 113.4 & 21.84 & 0.072 & 14.60 \\
\hline $\operatorname{LSD}(\mathrm{P}=.05)$ & - & - & 4.80 & 2.01 & 0.014 & 2.55 \\
\hline
\end{tabular}

Table.2 Effect of nitrogen management on yield attributes, grain and straw yields and benefitcost ratio of transplanted rice

\begin{tabular}{|c|c|c|c|c|c|c|c|}
\hline Treatment & $\begin{array}{l}\text { Length of } \\
\text { panicle } \\
\text { (cm) }\end{array}$ & $\begin{array}{c}\text { Grains } \\
\text { panicle }^{-1}\end{array}$ & $\begin{array}{c}\text { Test } \\
\text { weight } \\
\text { (g) }\end{array}$ & $\begin{array}{l}\text { Grain } \\
\text { yield } \\
\left(\mathbf{q} \text { ha }^{-1}\right)\end{array}$ & $\begin{array}{c}\text { Straw } \\
\text { yield } \\
\left(\mathrm{q} \mathrm{ha}^{-1}\right)\end{array}$ & $\begin{array}{l}\text { Harvest } \\
\text { index } \\
(\%)\end{array}$ & $\begin{array}{l}\text { B:C } \\
\text { ratio }\end{array}$ \\
\hline $\begin{array}{c}\mathrm{N} 1- \\
1 / 2+1 / 2\end{array}$ & 25.38 & 143.66 & 21.33 & 55.00 & 77.00 & 39.60 & 1.80 \\
\hline $\begin{array}{c}\mathrm{N} 2- \\
1 / 2+1 / 4+1 / 4\end{array}$ & 25.38 & 141.46 & 21.16 & 50.60 & 77.00 & 39.70 & 1.81 \\
\hline $\begin{array}{c}\mathrm{N} 3- \\
1 / 3+1 / 3+1 / 3\end{array}$ & 24.86 & 158.33 & 20.33 & 48.20 & 73.90 & 39.50 & 1.67 \\
\hline$\stackrel{\mathrm{N} 4-}{1 / 4+1 / 4+1 / 4+1 / 4}$ & 25.97 & 145.20 & 21.66 & 51.00 & 78.00 & 39.60 & 1.78 \\
\hline $\begin{array}{c}\mathrm{N} 5- \\
1 / 3+1 / 3+1 / 6+1 / 6\end{array}$ & 25.94 & 145.53 & 21.00 & 43.50 & 67.40 & 39.20 & 1.52 \\
\hline $\begin{array}{l}\text { N6- LCC3-20 kg basal }+23 \mathrm{~kg} \mathrm{~N}^{-1} \text { hased on } \\
\text { weekly reading }\end{array}$ & 24.34 & 140.66 & 19.66 & 42.30 & 65.90 & 39.10 & 1.50 \\
\hline $\begin{array}{c}\text { N7- LCC4-20 kg basal }+28 \mathrm{~kg} \mathrm{~N} \mathrm{ha}^{-1} \text { based on } \\
\text { weekly reading }\end{array}$ & 27.83 & 162.13 & 21.33 & 60.70 & 86.20 & 41.30 & 1.99 \\
\hline $\operatorname{LSD}(\mathrm{P}=.05)$ & NS & 6.6 & NS & 8.10 & NS & - & - \\
\hline
\end{tabular}

NS-Non-significant

\section{Productivity and profitability}

Grain yield of transplanted rice was significantly influenced by nitrogen management treatments (Table 2). However, they failed to exert any influence on straw yield. Grain yield (60.70 q ha ${ }^{-1}$ ) was obtained with nitrogen application based on LCC value of 4 (4 splits; $132 \mathrm{~kg} \mathrm{~N} \mathrm{ha}^{-1}$ ) compared to
LCC value 3 (4 splits; $112 \mathrm{~kg} \mathrm{~N} \mathrm{ha}^{-1}$ ) (42.30 q $\left.\mathrm{ha}^{-1}\right)$ but it was statistically on par with application of nitrogen in two splits $-1 / 2$ at basal, $1 / 2$ at active tillering (Table 2). Leaf nitrogen status of rice is closely related to photosynthetic rate and biomass production, and it is a sensitive indicator of changes in crop nitrogen demand within a growing season. Application of fertilizer nitrogen 
based on LCC value of 4 (4 splits; $132 \mathrm{~kg} \mathrm{~N}$ $\mathrm{ha}^{-1}$ ) was found effective to maintain optimal leaf nitrogen which resulted in better crop growth and high rice grain yield (Fig. 2). The reason may be same as explained earlier [5, $6]$.

Higher harvest index $(41.30 \%)$ in the LCC value 4 (4splits; $132 \mathrm{~kg} \mathrm{~N} \mathrm{ha}^{-1}$ ) than the fixed time recommended $\mathrm{N}$ application (39.70\%) suggested that fertilizer $\mathrm{N}$ applied on the basis of need of the plant was better translated into grain yield [7]. Application of $\mathrm{N}$ based on LCC value 4 (4splits; $132 \mathrm{~kg} \mathrm{~N} \mathrm{ha}{ }^{-1}$ ) also enhanced benefit-cost ratio (1.99) compared to blanket recommendation (1.81) with a saving of $18 \mathrm{~kg} \mathrm{~N} \mathrm{ha}^{-1}$.

LCC based nitrogen application enhance productivity and profitability of transplanted rice. Grain yield (60.70 $\mathrm{q} \mathrm{ha}^{-1}$ ) was obtained with nitrogen application based on LCC value of 4 (4 splits; $132 \mathrm{~kg} \mathrm{~N}^{-1}$ ) and saving of fertilizer $\mathrm{N}\left(18-25 \mathrm{~kg} \mathrm{~N}^{-1}\right.$ in transplanted rice). It is concluded that the LCC offers gigantic opportunities to increase $\mathrm{N}$ use efficiency, rice yield and net return for farmers in Allahabad region of Eastern Uttar Pradesh.

\section{Acknowledgment}

The authors are thankful to the Department of Agronomy, SHUATS, Allahabad and Nitrogen Parameters, A 32 III Floor, Avaram Block, Shanthi Niketan \#1 City Link Road, Adambakkam, Chennai - 600088, INDIA which provided LCC used in this study.

\section{References}

1. Singh H, Sharma KN, Gagandeep Singh Dhillon, Amanpreet, Tejdeep Singh, Vicky Singh, Dinesh Kumar, Bijay Singh, and Harmandeep Singh (2010). On-farm evaluation of real-time Nitrogen management in rice. Better Crops, 94(4): 26 $-27$.

2. IRRI (International Rice Research Institute) (1999). Reversing trends of declining productivity in intensive irrigated rice systems. Progress report 1998. Manila (Philippines): IRRI. 244 p.

3. Singh SP, Subbaiah SV, Kumar RM (2006). Response of rice varieties to nitrogen application time under direct seeded puddle condition. Oryza, 43(2): 157-158.

4. Peng S and Cassman KG (1998). Upper thresholds of nitrogen uptake rates and associated nitrogen fertiliser efficiencies in irrigated rice. Agronomy Journal, 90: 178 185.

5. Dhyani BP, Mishra B (1994). Scheduling nitrogen application for rice in mollisols. Oryza, 31: 202-205.

6. Pradeep K. Sharma and Masand SS (2008). Fertiliser N economy, soil nutrient status, water use efficiency and rice productivity with real-time nitrogen management and organic residues under irrigated and rainfed situations. Journal of the Indian Society of Soil Science, 56(2): 167 - 173.

7. Bijay, S., Gupta, R.K., Yadvinder, S., Gupta, S.K., Jag-deep, S., Bains, J.S., Vashishta, M. (2006). Need based nitrogen management using leaf colour chart in wet direct seeded rice in north western. Indian Journal of New Seeds 8(1): 35-47.

\section{How to cite this article:}

Sheikh Amir Ali, S. Elamathi, Suryendra Singh, Victor Debbarma and Gautam Ghosh. 2017. Leaf Colour Chart for Proficient Nitrogen Management in Transplanted Rice (Oryza sativa L.) in Eastern Uttar Pradesh, India. Int.J.Curr.Microbiol.App.Sci. 6(11): 5367-5372. doi: https://doi.org/10.20546/ijcmas.2017.611.513 